\title{
Risk factors for infection with human immunodeficiency virus among European expatriates in Africa
}

Luc Bonneux, Patrick Van der Stuyft, Henri Taelman, Phillippe Cornet, Christian Goilav, Guido van der Groen, Peter Piot

\begin{abstract}
The pattern of cases of AIDS in Belgium suggests that Europeans infected with human immunodeficiency virus (HIV) acquired the infection in Africa. The prevalence of infection was assessed in Belgian advisers and European expatriates and risk factors for infection defined in a case-control study of expatriate men. Fifteen $(1 \cdot 1 \%)$ of 1401 Belgian advisers working in Africa and $41(0.9 \%)$ of 4564 European expatriates living in Africa, were positive for antibody to HIV in a voluntary screening programme in Belgium. Among subjects with antibody to HIV the ratio of men to women was $3: 1$. These subjects did not have a history of intravenous drug abuse or blood transfusion and only one was homosexual. In a case-control study of 33 expatriate men who had antibody to HIV and 119 controls the men with antibody reported significantly more female sexual partners, who were more commonly local; and significantly more sexual contact with prostitutes in Africa. They had a significantly higher prevalence of history of sexually transmitted disease and had received significantly more injections by unqualified staff in Africa during the previous five years. No specific sexual practices were associated with having antibody to HIV. After multivariate analysis sexual contact with local women (adjusted odds ratio $14.7 ; 95 \%$ confidence interval 2.81 to 76.9), sexual contact with prostitutes (adjusted odds ratio 10.8 (1.6 to 71.9$)$, and injections by unqualified staff (adjusted odds ratio 13.5 (3.7 to 49.8) remained independent risk factors for infection.

European expatriates in Africa were at increased risk from infection with HIV and were a means of introducing HIV into the heterosexual population in Europe. Transmission from women to men by vaginal intercourse seemed to be the most probable route of infection.
\end{abstract}

\section{Introduction}

From the start of the current epidemic of AIDS most adult patients with AIDS in Europe and the United States have been homosexual or bisexual men or intravenous drug users. In Belgium, however, this is not the case: $164(49 \%)$ of 336 patients with AIDS reported by March 1988 were of African descent, and $43(33 \%)$ of 129 patients of European descent with AIDS seen until 1987 were directly associated with Africa because they travelled or lived there or because of sexual activity.' Among European patients with AIDS who lived outside Belgium the ratio of men to women was $2 \cdot 3: 1$, compared with a ratio of $13: 1$ in the United States and 10.5:1 in Europe." Among these patients homosexual contacts, intravenous drug use, haemophilia, or a history of blood transfusion accounted for only $13 \%$ of cases. These data are more consistent with epidemiological patterns of infection with human immunodeficiency virus (HIV) in Africa, where bidirectional heterosexual transmission is the main mode of spread. ${ }^{+5}$ Thus Belgium seems to be at the intersection of two main patterns of transmission of HIV in the world.

We describe a survey of the prevalence of infection with HIV among Belgian advisers and European expatriates living in Africa and a case-control study to define the risk factors for infection with HIV in this population.

\section{Subjects and methods}

Between June 1985 and July 1987 we tested Belgians working in developing countries and their families for antibody to HIV as part of a yearly or two yearly occupational medical examination at the clinic of the Ministry of Foreign Affairs in Brussels. Participation in the screening programme was voluntary. In addition, we offered testing for antibody to HIV at the outpatient clinic of the Institute of Tropical Medicine in Antwerp, which is attended by travellers from the tropics and expatriates living in developing countries, mainly in central Africa.

We enrolled men over age 18 of European descent and nationality who had antibody to HIV on screening at either clinic into a case-control study if they had been in Africa for at least six months within the past five years and were available for interview. We limited the case-control study to men as we detected only 14 women who had antibody to HIV. The controls were men (aged over 18) of European descent and nationality who did not have antibody to HIV in the same screening programmes. They were eligible if they had stayed in subsaharan Africa for at least two years during the past five years or were on an overseas contract with the Belgian government there. Between December 1986 and April 1987 at this institute we selected controls who did not have symptoms if they had been seen for a preventive medical examination by the same doctor who had enrolled a patient with antibody to HIV. Overall we received $2 \cdot 7$ controls per case in this way. We selected as an additional control group consecutive subjects who attended the clinic of the Ministry of Foreign Affairs between 27 July and 7 August, 1987. A total of 131 men who did not have antibody were selected in the two clinics, of whom seven refused to participate.

We maintained confidentiality in this screening programme by giving test results only to the participants and to a doctor of their choice but not to other people or bodies, such as their employer. Less than $5 \%$ of those attending the clinics elected not to participate in the screening programme. We obtained informed consent from all subjects and asked participants in the case-control study to complete a self administered 
questionnaire, which included questions on sociodemographic characteristics and risk factors for infection with HIV. The respondents were classified as heterosexual if they denied any sexual contact with people of the same sex during their lifetime and as not using drugs if they stated that they did not use illicit intravenous drugs.

HIV antibody state was determined with an enzyme immunoassay (Organon Teknika, Oss, The Netherlands) and positive reactions were confirmed with indirect immunofluorescence and immunoblotting. ${ }^{6}$ Serological testing for syphilis included the rapid plasma reagin test (Becton Dickinson, Baltimore, Maryland) and the Treponema pallidum haemagglutination assay (Fujizoki, Japan). Hepatitis markers were determined in enzyme immunoassays (Abbott Laboratories, North Chicago, Illinois).

For the categorical variables we performed univariate analysis with the $\chi^{2}$ test, the $\chi^{2}$ test for trends, and Fisher's exact test, and for the continuous variables we performed the $t$ test. Variables that were significantly associated with infection with HIV in the univariate analysis, together with those that were not significantly associated but were potentially relevant, were entered into a linear logistic regression model..$^{78}$

\section{Results}

PREVALENCE OF INFECTION WITH HIV

Over two years 56 expatriates with antibody to HIV (42 men and 14 women; ratio of men to women $3: 1$ ) were identified in the screening programmes. Though exact data were missing, European expatriate men in Africa largely outnumbered expatriate women. Fifteen official advisers and volunteers employed in Rwanda, Burundi, or Zaire had antibody to HIV, resulting in a prevalence of $1 \cdot 1 \%$ among the 1401 Belgian advisers living in these three countries who participated in the screening programme. Forty one expatriates with antibody to HIV were detected among 4564 patients screened at the institute, resulting in a prevalence of $0.9 \%$. This population included spouses and children of expatriates; subjects living outside central Africa, where infection with HIV is believed to be less common; and people consulting more than once.

\section{CHARACTERISTICS OF SUBJECTS WITH ANTIBODY TO HIV}

Among the 14 women who had antibody to HIV two had received a blood transfusion in Africa, seven were regular sexual partners of a man confirmed to have antibody, two were partners of European expatriates who were not tested, and two were partners of Africans who were not tested; in one a presumptive risk factor could not be identified. Of the 42 men who had antibody, none had used intravenous drugs or had a blood transfusion and only one (2\%) reported homosexual contacts. (He was not enrolled into the casecontrol study because he was not in Belgium at that time.) All but two men lived in Rwanda, Burundi, or Zaire; one lived in Tanzania and the other in Uganda.

Hepatitis B markers were found in 13 of $47(28 \%)$ subjects who had antibody to HIV, and positive results on testing for syphilis in five (11\%); these figures compared with $17(15 \%)$ and none, respectively, among the 112 Belgian expatriates living in central Africa who did not have the antibody.

\section{RISK FACTORS FOR INFECTION WITH HIV}

Of the men selected for the case-control study, 33 $(92 \%)$ of the 36 with antibody to HIV completed the questionnaire and 119 of the 124 controls gave sufficient information for analysis. Table I shows selected demographic characteristics of the two groups. Both groups were similar with regard to age, duration
TABLE I-Selected characteristics of European expatriate men in Africa with antibody to HIV and controls

\begin{tabular}{|c|c|c|c|}
\hline & $\begin{array}{c}\text { Men with } \\
\text { antibody } \\
(\mathrm{n}=33)\end{array}$ & $\begin{array}{l}\text { Controls } \\
(n=119)\end{array}$ & $\mathrm{p}$ Value \\
\hline Mean (SD) age (years) & $40 \cdot 8(9 \cdot 1)$ & $41 \cdot 5(10 \cdot 7)$ & $>0 \cdot 1$ \\
\hline \multicolumn{4}{|l|}{ No $(\%)$ educated $d^{\star}$ : } \\
\hline To sage 18 & $15(45)$ & $19(16)$ & \\
\hline To >age 18 & $16(48)$ & $97(82)$ & $<0.001$ \\
\hline \multicolumn{4}{|l|}{ No (\%) living in: } \\
\hline $\begin{array}{l}\text { Rwanda, Burundi, } \\
\text { Zaire }\end{array}$ & $32(97)$ & $95(80)$ & \\
\hline Other African country & $1(3)$ & $24(20)$ & 0.07 \\
\hline \multicolumn{4}{|l|}{ No $(\%)$ living in Africa: } \\
\hline$<2$ years & $2(6)$ & $6(5)$ & \\
\hline $2-5$ years & $10(30)$ & $34(29)$ & $>0.1$ \\
\hline$>5$ years & $21(64)$ & $79(66)$ & \\
\hline \multicolumn{4}{|l|}{ No $(\%)$ dental } \\
\hline interventions & $15(45)$ & $75(63)$ & $>0 \cdot 1$ \\
\hline $\begin{array}{r}\text { No (\%) surgical } \\
\text { interventions }\end{array}$ & $1(3)$ & $3(3)$ & $>0 \cdot 1$ \\
\hline
\end{tabular}

${ }^{\star}$ Data missing for two men with antibody and three controls.

of stay in Africa, and clinic where recruited. Significantly higher proportions of men who had antibody, however, had not been educated beyond 18 years of age and live in Burundi, Rwanda, and Zaire than in other parts of Africa.

Men with antibody to HIV had had significantly more heterosexual partners, more African sexual partners, and more contacts with prostitutes during the previous five years, and they also reported significantly more episodes of sexually transmitted diseases (table II). The median number of African sexual partners and contacts with prostitutes were six and nine, respectively, for the men who had antibody compared with one and none, respectively, for the controls. The number of regular sexual partners (defined as a sexual partner for at least six months) did not differ between the groups. In general, specific sexual practices were not associated with having antibody to HIV and thus the groups did not differ in the use of condoms $(39 \%(13)$ in cases $30 \%$ (36) in controls) and in their practice of orogenital or anorectal sex. Surgical and dental interventions and a history of injections in Africa during the previous five years were not associated with having antibody to HIV Expatriates who had antibody, however, tended to have a history of injections given by unqualified staff (odds ratio $5 \cdot 47 ; 95 \%$ confidence interval $1 \cdot 34$ to $23 \cdot 3$ ).

Logistic regression analysis did not show significant interaction effects between the variables. After controlling for confounding factors the significant risk factors for infection with HIV were the number of African sexual partners, sexual contact with prostitutes in Africa, and injections by unqualified staff (table III). As in the univariate analysis the risk increased with increasing sexual exposure to local women or prostitutes. The level of education remained an independent risk factor but with a moderate odds ratio.

\section{Discussion}

About $1 \%$ of European expatriates from two fairly large samples of advisers and volunteers screened at their yearly or two yearly medical examination had evidence of infection with HIV; the samples were representative as almost all Belgian overseas advisers participated in the programme. This prevalence is about 250 times higher than that among Belgian blood donors, of whom $0.004 \%$ had antibody to HIV in 1986 (National AIDS Commission, unpublished data). In a smaller survey of Danish volunteers returning from Africa $8.6 \%$ were positive for antibody to HIV. ${ }^{9}$ In the Danish study, however, only $38 \%$ of the eligible subjects agreed to be tested for the antibody, compared with over $95 \%$ in the Belgian survey.

These data show that infection with HIV is spreading in a heterosexual Belgian population that is other- 
African populations, all of which suggested that bidirectional heterosexual transmission was the main mode of spread of infection with HIV in Africa. ${ }^{+}$Sexual intercourse with prostitutes was also a potential risk factor among heterosexual men with AIDS in the United States, of whom $34 \%$ were reported to have had sexual contact with female prostitutes. ${ }^{13}$ This figure, however, is close to the rate of contact with prostitutes in our control population, showing the need for well controlled studies on sexual behaviour in heterosexual populations potentially at risk of infection with HIV. Condoms were seldom used and often improperly used in our study population. The only man who had antibody who frequently used condoms did not do so properly, putting them on after the first vaginal penetration.

The role of contaminated injections in spreading infection with HIV in the Third World has not been satisfactorily resolved. This issue is important as exposure to intramuscular injections with non-sterile needles and syringes for medical or paramedical reasons may be common in many developing countries. Populations such as expatriates may provide some information because they probably have a lower background exposure to such injections. Our data suggest that injections for medical reasons may have a limited role in transmitting infection with HIV in Africa. This complex issue clearly, however, requires further study as the available data conflict (B N'galy et al, paper presented at third international conference on AIDS, Washington, DC, 1987.) $)^{1+15}$

Only injections administered by "injectionists" or in unsupervised dispensaries were a significant risk factor for acquiring antibody to HIV in this study, and the association was independent of other variables such as level of education, history of sexually transmitted disease, and sexual contact with prostitutes. This observation is compatible with the fact that injections given by poorly trained or unsupervised staff are more likely to have been given with improperly sterilised needles and syringes. The only two men who had antibody to HIV and denied having had sexual contact with local women had a history of parenteral exposure in Africa; one was a surgeon who had experienced multiple needlestick injuries and cuts and the other had received an intravenous injection of quinine for presumed cerebral malaria in a rural private dispensary that was run by unsupervised and almost untrained staff.

We conclude that there is no evidence for modes of transmission of infection with HIV among expatriates in Africa other than sexual contact or injections, as all cases could be attributed to these two modes. Though blood transfusions were not reported in our study population, they were the attributable risk factor in two of 14 women detected as having antibody to HIV in the screening programme. Such cases will continue to occur until all donations of blood are screened for the antibody. If HIV is transmitted in Africa by casual contact or insects it is hard to explain why none of the children of Belgian expatriates gave positive results for antibody on screening. This confirms data from other studies, in which no evidence for these two modes of transmission was found. ${ }^{16} 17$

Our results show an additional route whereby HIV may be introduced into the heterosexual population in Europe and North America, besides by abusers of intravenous drugs and bisexual men. The epidemiological data on AIDS in Belgium show that heterosexuals account for a significant proportion of cases in a European population and that secondary spread to the local population in Belgium is already occurring ( $N$ Clumeck et al, paper presented at third international conference on AIDS, Washington, DC, 1987). Thus heterosexual transmission of HIV may become more common in continents other than Africa. 
We thank the physicians at the Leopold II Clinic and the medical centre of the Ministry of Foreign Affairs for their cooperation, and G Vercauteren and V Hanquart for the laboratory testing. The screening programme was funded by the General Administration of Cooperation Development, and the study was supported by the Ministry of Health in Brussels.

1 Instituut voor Hygiène en Epidemiologie. AIDS in België. 3I Maart 1988. Brussels: Ministry of Health, 1988.

2 Curran JW, Jaffe HW, Hardy AM, Morgan WM, Selik RM, Dondero TJ. Epidemiology of HIV infection and AIDS in the United States. Science 1988;239:610-6.

3 World Health Organisation Collaborating Centre on AIDS, Paris. AIDSsurveillance in Europe: situation by 31 December 1987. Paris: WHO, 1988. (Report No 10.)

4 Quinn TC, Mann JM, Curran JW, Piot P. AIDS in Africa: an epidemiologic paradigm. Science 1986;234:955-63.

5 Piot P Plummer FA, Mhalu FS, Chin J, Lamboray JL, Mann JM. AIDS: an international perspective. Science 1988;239:573-9.
in

6 Vercauteren G, Piot P, van der Groen G. Comparison of enzyme immunoassays and an immunofluorescence test for detection of antibody to human immunodeficiency virus in African sera. European fournal of Microbiologv 1987;6:132-5

7 Kleinbaum DG, Kupper LL, Morgenstern H. Epidemiologic research; prin- ciples and quantitative methods. London: Lifetime Learning Publications (Wadworth), 1982

8 Brestow NE, Day NE. Statistical methods in cancer research. Vol I. The analysis of case-control studies. Lyons: International Agency for Research on Cancer, of case-control studies. Lyons: Internation

9 Tauris P, Black FT. Heterosexuals importing HIV from Africa. Lancet 1987; i:325.

10 Piot P, Plummer FA. Rey MA, et al. Retrospective seroepidemiology of AIDS virus infection in Nairobi populations. I Infect Dis 1987;155:1108-12.

11 Van de Perre P, Clumeck N, Carael $M$, et al. Female prostitutes: a risk group for infection with the human T cell lymphotropic virus type III. Lancel 1985;ii:524-6.

12 Vittecoq D, Roue RT, Mayaud C, et al. Acquired immunodeficiency syndrome after travelling in Africa: an epidemiological study in seventeen Caucasian patients. Lancet 1987; i:612-4.

13 Centers for Disease Control. Heterosexual transmission of HTLV III/LAV. $M M W R$ 1985;34:2051-2.

14 Mann JM, Francis H, Davachi F, et al. Risk factors for human immunodeficiency virus seropositivity among children 1-24 months old in Kinshasa, Zaire. Lancet 1986;ii:654-6.

15 Lepage P, van de Perre P, Caraël M, Butzler JP. Are medical injections a risk factor for HIV infection in children? Lancet 1986;ii: 1103-4.

16 Mann JM, Francis H, Quinn TC, et al. Surveillance among household members of confirmed AIDS-cases and controls in Kinshasa, Zaire. JAMA 1986;256:721-4

17 Friedland GH, Saltzman BR, Roger MF, et al. Lack of transmission of HTLVIII/LAV infection to household contacts of patients with AIDS or AIDSrelated complex with oral candidiasis. $N$ Engl f Med 1986;314:344-9.

(Accepted 16 fune 1988)

\title{
A prospective study of maternal and fetal outcome in acute Lassa fever infection during pregnancy
}

\author{
Michael E Price, Susan P Fisher-Hoch, Robert B Craven, Joseph B McCormick
}

\begin{abstract}
Several viral infections have been reported to result in more severe disease in pregnant than non-pregnant women, but the relative risks have not been well characterised. This has now been done for Lassa fever in a prospective study of 68 pregnant and 79 non-pregnant women who were admitted to hospital in Sierra Leone with confirmed Lassa fever. Lassa fever was the main cause of maternal mortality in the hospital, accounting for $25 \%$ of maternal deaths. Twelve of $\mathbf{4 0}$ patients in the third trimester died, compared with two of 28 in the first two trimesters and 10 of 79 non-pregnant women. The odds ratio for death in the third trimester compared with the first two trimesters was 5.57 (95\% confidence intervals 1.02 to 30.26$)$. The condition of the mother improved rapidly after evacuation of the uterus, whether by spontaneous abortion, evacuation of retained products of conception, or normal delivery; 10 of 26 women without uterine evacuation died, but only four of 39 women with evacuation died $(p=0.0016)$. The odds ratio for death with pregnancy intact was 5.47 (95\% confidence interval 1.35 to $22 \cdot 16$ ). Fetal and neonatal loss was $87 \%$.
\end{abstract}

The risk of death from Lassa fever in the third trimester is significantly higher than that in the first two trimesters and higher than that for non-pregnant women, but evacuation of the uterus can significantly improve the mother's chance of survival.

Nixon Memorial Hospital, Segbwema, Sierra Leone Michael E Price, MRCP

Centres for Disease Control Center for Infectious Diseases, Division of Viral Diseases, Special Pathogens Branch, Atlanta, GA 30333 , United States

Susan P Fisher-Hoch, MD Joseph B McCormick, MD Robert B Craven, MD

Correspondence to: Dr FisherHoch. age who had been admitted to hospital with Lassa fever.

Lassa fever is endemic in eastern Sierra Leone, where it is an important cause of admission to hospital and death. ${ }^{3}$ We have isolated the Lassa fever virus from fetal organs after spontaneous abortion and have obtained the highest titres of virus from human placenta.$^{3.5}$ In two early investigations, which reported eight maternal deaths due to Lassa fever, ascertainment of cases was uncertain and data were poorly substantiated. ${ }^{67}$ To provide accurate data on the risk of death and complications of Lassa fever in pregnancy. we studied 68 pregnant patients with Lassa fever during the four years $1981-5 .^{589} \mathrm{We}$ studied pregnant women requiring admission to hospital and did not include febrile pregnant women treated in antenatal clinics and not admitted to hospital.

\section{Patients and methods}

Febrile women with complications of pregnancy admitted to the Nixon Memorial Hospital, Segbwema, either from an antenatal clinic or through the medical outpatient clinic were routinely investigated for clinical and laboratory evidence of Lassa fever. Lassa fever was confirmed by finding on immunofluorescence a fourfold rise in the titre of IgG to Lassa fever virus (minimum final titre of 16 ) or an IgG titre of $\geqslant 256$ with IgM antibody to Lassa fever, or by isolating the virus. The duration of gestation was estimated from the height of the uterine fundus because patients could rarely give accurate dates of their last menstrual period. The controls in this study were the women of childbearing age who were admitted to hospital with confirmed Lassa fever and in whom pregnancy was excluded.

Haemoglobin concentration, white cell and platelet counts and serum aspartate transaminase activity were measured and urine analysed for all patients on admission and during the course of the illness at the hospital laboratories and the Sierra Leone Ministry of Health and Centers for Disease Control Lassa fever research project laboratory at the hospital. Facilities for bacteri- 